\title{
Dysphagia and its relation with nutritional status and calorie/protein intake in the elderly
}

\author{
Laura Mata de Lima Silva ${ }^{1}$ \\ https://orcid.org/0000-0002-6893-9781 \\ Cybelle Rolim de Lima ${ }^{2}$ \\ https://orcid.org/0000-0002-9621-5983 \\ Daniele Andrade da Cunha ${ }^{3}$ \\ https://orcid.org/0000-0002-3987-9740 \\ Luciana Gonçalves de Orange ${ }^{2}$ \\ https://orcid.org/0000-0002-7624-1498
}

\begin{abstract}
Hospital dos Servidores do Estado,Programa de Residência em Nutrição Clínica, Recife, Pernambuco, Brasil.

Universidade Federal de Pernambuco, Núcleo de Nutrição do Centro Acadêmico de Vitória de Santo Antão, Vitória de Santo Antão, Pernambuco, Brasil. Universidade Federal de Pernambuco, Departamento de Fonoaudiologia, Recife, Pernambuco, Brasil.
\end{abstract}

Conflict of interests: Nonexistent

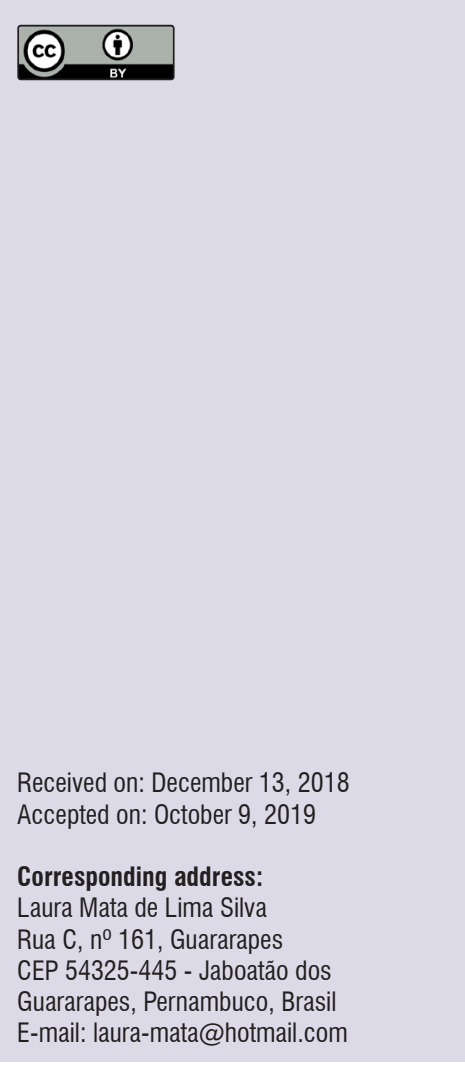

\section{ABSTRACT}

Purpose: to evaluate the nutritional status associated with dysphagia, and compare the calorie and protein intake of dysphagic elderly patients to that of non dysphagic ones, during hospitalization.

Methods: this is a cross-sectional study with elderly people ranging from 60 to 80 years old admitted as inpatients in a medical and neurological clinic of a public hospital. They formed two groups, according to the presence of dysphagia: dysphagic and non dysphagic ones. The inclusion criteria were: dysphagia secondary to stroke and exclusive oral feeding. Anthropometric measurements and the Mini-Nutritional Assessment (MNA) were applied. The 24-hour recall was used to analyze food consumption. The statistical analysis used the Fisher's exact test for the association of variables, and the Mann-Whitney test, for their comparison.

Results: a total of 12 elderly people participated, whose mean age was $70.50 \pm 7.77$ years in the dysphagia group $(n=6)$, and $72.67 \pm 5.01$ years in the non dysphagia group $(n=6)$. There was an association between the presence of dysphagia and the risk of malnutrition, according to MNA ( $p=0.028)$. No significant difference in calorie and protein intake was seen between the groups. The group with dysphagia had a lower water intake as compared to the non dysphagia group $(p=0.045)$.

Conclusion: dysphagia was associated with the risk of malnutrition and lower fluid intake in dysphagic patients, thus, increasing their risk of dehydration.

Keywords: Swallowing Disorders; Stroke; Nutritional Assessment; Food Intake; Aging 


\section{INTRODUCTION}

Dysphagia is defined as the difficulty to start the swallowing process, named oropharyngeal dysphagia, or the sensation that the solid or liquid foods are stuck in the transition from the mouth to the stomach, named esophageal dysphagia. It is the perception that the normal passage of swallowed content is hindered'. This difficulty may be caused by behavioral or sensorial factors, motor actions preceding the act of swallowing, the cognitive awareness related to the recognition of the act of feeding, the visual aspects of food, and the physiologic responses triggered by the smell and presence of food ${ }^{2}$. The oropharyngeal swallowing involves a set of quickly happening and highly coordinated neuromuscular actions, starting with lip closure and ending with the opening of the upper esophageal sphincter. The central coordination of this complex sensorimotor and semiautomatic activity uses a scattered network of cortical, subcortical and brain stem structures ${ }^{3}$.

Diseases and disorders affecting the central swallowing region and/or peripheral nerves, muscles and structures involved may result in impairment of oropharyngeal swallowing, causing oropharyngeal dysphagia, which is a common and lethal symptom of neurologic diseases. Dysphagia may affect at least $50 \%$ of the patients victims of stroke, both of the hemorrhagic and the ischemic type; $60 \%$ of the individuals with severe traumatic brain injury; approximately $30 \%$ of those with amyotrophic lateral sclerosis at the moment of diagnosis, and all of those during the progression of the disease ${ }^{3}$; and $52 \%$ to $82 \%$ of the Parkinson's patients. Dysphagia is the main risk factor for aspiration pneumonia, representing a frequent cause of death in this population ${ }^{3}$ and in $57 \%$ to $84 \%$ in those with Alzheimer's disease ${ }^{4}$.

In the elderly presenting dysphagia, there is an increase in the prevalence of malnutrition of $36.8 \%$, and of nutritional risk of $55.3 \%$, which is significantly higher when these elderly are compared to those without dysphagia $^{5}$. Dysphagic patients present a decrease in food intake, and consequently a low energetic-protein intake in relation to the nutritional needs ${ }^{6}$. Malnutrition secondary to the decrease in food consumption causes progressive weight loss and muscle mass depletion, diminishing the strength of the muscles responsible for the swallowing process, thus increasing the severity of the dysphagia?.

Dehydration is also a problem that may occur during treatment due to the need to thicken the liquids and suspend the thin ones so as to avoid the risk of aspiration $^{8}$. The swallowing of thin liquids demands greater control and coordination, and so they are easily aspired. Elderly patients are more prone to the occurrence of aspirations resulting from weakness caused by muscle and/or neurologic alterations ${ }^{6}$. Moreover, xerostomia, and alterations in taste and smell related to age may also negatively interfere with swallowing ${ }^{2}$.

Dysphagia treatment requires the work of a transdisciplinary team, since dysphagia affects the quality of life and the overall well-being of the person ${ }^{2}$. The speech-language-hearing therapist is the professional skilled to assess, define and/or alter the therapeutic procedures in dysphagia, and is the one responsible for allowing the patient to feed themselves according to their condition. They must work in partnership with a nutritionist, who is the professional responsible for ensuring the offer of an adequate amount of energy and nutrients, aiming at recovering and/or maintaining the nutritional status based on a diet adapted to the conditions and needs of the patient, preventing aspiration to occur $^{9}$, and considering the adequate provision of liquids to avoid dehydration ${ }^{7}$.

The purpose of this research was to assess nutritional status, relating it to the presence of dysphagia, and compare the calorie and protein intake of dysphagic and non dysphagic elderly during hospital stay.

\section{METHODS}

The study was submitted to the Research on Humans Ethics Committee of the Universidade Federal de Pernambuco under evaluation report no. 915.415 and approved under Certificate of Presentation for Ethical Consideration number 30259114.8.0000.5208. The participants and/or their guardians signed an Informed Consent Form to participate in the research.

This is a descriptive, cross-sectional study, conducted with the elderly in an inpatient medical and neurologic clinic of a public hospital, who were using 23 of its beds, regardless of diagnosis of speechlanguage-hearing assessment. Elderly in the age range of 60 to 80 years, whose feeding was exclusively oral, were selected to form two groups, according to dysphagia diagnosis: dysphagic and non dysphagic elderly. For the dysphagic elderly group, individuals with dysphagia secondary to stroke were selected. The exclusion criteria were: use of alternative feeding routes, physical limitations for nutritional assessment due to amputation, edema and/or ascites, and palliative care. 
The assessment of the nutritional status was conducted by means of the anthropometric parameters (body mass index, arm circumference and calf circumference) and the Mini-Nutritional Assessment $(\mathrm{MNA})^{10}$. The walking elderly were weighed in digital scale $\left(\right.$ CAMRY $^{\circledR}$ EB9013, China) with capacity of 150 $\mathrm{kg}$ and precision of $100 \mathrm{~g}$. Those restricted to bed had their weight estimated through Lee and Nieman's equation ${ }^{11}$, using the arm circumference (AC) and leg length (knee-high, or $\mathrm{KH}$ ) measurements, according to gender, age and ethnicity. The elderly stature was estimated with the equation proposed by Chumlea, Roche e Steinbaugh ${ }^{12}$, according to gender. Body mass index (BMI) was calculated with the weight and height data obtained, using the formula: [weight $(\mathrm{kg})] /$ [height $\left(\mathrm{m}^{2}\right)$ ], and expressing the result in $\mathrm{kg} / \mathrm{m}^{2}$. The nutritional status classification by BMI considered Lipschitz's criterion $^{13}$, which classifies a value lower than22 $\mathrm{kg} / \mathrm{m}^{2}$ as indicative of malnutrition; from $22 \mathrm{~kg} /$ $\mathrm{m}^{2}$ to $27 \mathrm{~kg} / \mathrm{m}^{2}$, of eutrophy; and higher than $27 \mathrm{~kg} / \mathrm{m}^{2}$, of excessive weight.

The AC and the calf circumference (CC) were measured with an inelastic flexible measuring tape. The $A C$ adequacy percentage was verified through the formula: [AC obtained $(\mathrm{cm})] \times 100 /$ [AC percentile 50], considering the references values of the percentile 50 of the Third National Health and Nutrition Examination Survey (NHANES III) ${ }^{14}$, and the classification of the nutritional status proposed by Blackburn e Thorton ${ }^{15}$. For the classification of the $\mathrm{CC}$, the cutoff score for eutrophy was set as value equal to or higher than 31 $\mathrm{cm}^{16}$.

The MNA was applied to all the elderly. This assessment is composed of questions whose score ranges from 0 to 3 , and contributes to the final score, whose maximum value is 30 . The interpretation is based on the total score. When the total sum is lower than 17 points, it represents malnutrition; from 17 to 23.5 points, risk of malnutrition; and equal to or higher than 24 points, eutrophy ${ }^{10}$.

The calorie and protein need estimate was established considering the nutritional status and the disease of the person. The energetic need was calculated according to Harris-Benedict equations ${ }^{17}$, multiplying the result by the activity factor (AF) and injury. The proteic need was calculated considering a supply of 1.0 to $1.5 \mathrm{~g}$ of protein $/ \mathrm{kg}$ of weight $/$ day ${ }^{18}$.

In the food intake assessment, the qualitative and quantitative composition of the hospital's dietary standard was considered. Daily records concerning four days (three weekdays and one on the weekend) were collected. To calculate calorie and protein intake, The Brazilian Food Composition Table ${ }^{19}$ and the Nutritional Composition Table of the Instituto Brasileiro de Geografia e Estatística ${ }^{20}$ were used. The composition of some industrialized foods not included on these tables was obtained through consultation of the nutritional facts available on their labels. The liquid intake was also verified in the two groups, their average consumption being calculated based on the analyzed 24-hour recall.

The speech-language-hearing assessment was considered precocious when performed within 48 hours of hospital admission upon medical request, in accordance with the institution's protocol ${ }^{21}$. The records of speech-language-hearing care were collected from the medical records. Oral feeding was classified according to FOIS - Functional Oral Intake Scale, which was applied by the hospital's speech-language-hearing team. The Scale classifies as level 1: nothing through oral route; level 2: dependence on alternative route, and minimum attempt to ingest any food or liquid through oral route; level 3: dependence on alternative route, and consistent oral ingestion of some food or liquid; level 4: exclusive oral diet of only one consistency; level 5: exclusive oral diet with many consistencies, though with the need of some special preparation or compensation; level 6: exclusive oral diet with many consistencies, without the need of special preparation, but with specific dietary restrictions; and, level 7: exclusive oral diet, without restrictions ${ }^{22}$.

The statistical analysis was conducted on the SPSS software, version 13.0 for Windows, applying the tests with $95 \%$ confidence and considering the significance level of $p<0.05$. Fisher's exact test was applied in order to verify the association between the variables, and the Mann-Whitney test for the comparison of the variables with not normal distribution between the groups.

\section{RESULTS}

A total of 12 elderly were assessed, $75 \%$ of them being women $(n=9)$. The age average found was of $70.50 \pm 7.77$ years in the group with dysphagia ( $\mathrm{n}$ $=6$ ), and of72.67 \pm 5.01 years in the group without dysphagia $(n=6)$. Only $33.3 \%(n=2)$ of the patients with dysphagia were assessed by the speechlanguage-hearing team within 48 hours of admission. All of them presented oropharyngeal dysphagia. Of these patients, $83.3 \%(n=5)$ were classified on level 4 of the FOIS scale, and $16.7 \%(n=1)$ on level 6 . There 
were no reports on the medical records regarding degree of dysphagia. The prescription of liquid thickeners was given to all the patients in the dysphagic group. The characterization of the sample is described on Table 1. There was no association between the clinical variables and the presence of dysphagia. The main reason for hospital admission was stroke, present in $33.3 \%(n=4)$ of the total sample, $50 \%(n$ $=3$ ) of them in the dysphagic group, and $16.7 \%$ ( $n=$ 1) in the nondysphagic group, followed by infectious diseases. The group of dysphagic elderly presented a prevalence of arterial hypertension, diabetes mellitus and heart diseases. In addition, there was found in this group a greater number of elderly with previous history of stroke, with an average number of stroke episodes equivalent to $2.17 \pm 1.47$, against $1.00 \pm 0.00$ in the non dysphagic group. Only one patient in the dysphagic elderly group who had previous history of stroke was admitted due to a new episode. Approximately $66.7 \%$ $(n=4)$ of the dysphagic patients had post-stroke chronic oropharyngeal dysphagia, and $33.3 \%(n=2)$, acute.

Table 1. Characterization of the sample of dysphagic and non dysphagic elderly hospitalized in a public hospital. Recife, Pernambuco, Brazil, 2015

\begin{tabular}{|c|c|c|c|c|}
\hline \multirow{3}{*}{ Variables } & \multicolumn{3}{|c|}{ Dysphagia } & \multirow{3}{*}{ P- value* } \\
\hline & Total & Yes & No & \\
\hline & n (\%) & n (\%) & $\mathrm{n}(\%)$ & \\
\hline \multicolumn{5}{|l|}{ Gender } \\
\hline Males & $3(25.0)$ & $1(16.7)$ & $2(33.3)$ & 1.000 \\
\hline Females & $9(75.0)$ & $5(83.3)$ & $4(66.7)$ & \\
\hline \multicolumn{5}{|c|}{ Reason for hospitalization } \\
\hline Stroke & $4(33.3)$ & $3(50.0)$ & $1(16.7)$ & 0.494 \\
\hline Infection & $3(25.0)$ & $2(33.3)$ & $1(16.7)$ & \\
\hline Respiratory disease & $2(16.7)$ & $0(0.0)$ & $2(33.3)$ & \\
\hline Other causes & $3(25.0)$ & $1(16.7)$ & $2(33.3)$ & \\
\hline \multicolumn{5}{|c|}{ Presence of diabetes mellitus } \\
\hline Yes & $6(50.0)$ & $4(66.7)$ & $2(33.3)$ & 0.567 \\
\hline No & $6(50.0)$ & $2(33.3)$ & $4(66.7)$ & \\
\hline \multicolumn{5}{|c|}{ Presence of arterial hypertension } \\
\hline Yes & $7(58.3)$ & $5(83.3)$ & $2(33.3)$ & 0.242 \\
\hline No & $5(41.7)$ & $1(16.7)$ & $4(66.7)$ & \\
\hline \multicolumn{5}{|c|}{ Previous history of stroke } \\
\hline Yes & $5(41.7)$ & $4(66.7)$ & $1(16.7)$ & 0.242 \\
\hline No & $7(58.3)$ & $2(33.3)$ & $5(83.3)$ & \\
\hline \multicolumn{5}{|c|}{ Presence of heart diseases } \\
\hline Yes & $2(16.7)$ & $2(33.3)$ & $0(0.0)$ & 0.455 \\
\hline No & $10(83.3)$ & $4(66.7)$ & $6(100.0)$ & \\
\hline
\end{tabular}

$\left.{ }^{*}\right)$ Fisher's exact test for the association of the variables

In the assessment of anthropometric measurements, described on Table 2, a greater number of eutrophic individuals was identified according to the AC and CC classification, and excessive weight according to the BMI, without significant difference between the groups. The weight was estimated in $83.3 \%(n=5)$ of the elderly with dysphagia, and in $33.3 \%(n=2)$ of the elderly without dysphagia. The average value of the anthropometric indicators in the group with dysphagia was of: $26.14 \pm 3.97 \mathrm{~kg} / \mathrm{m}^{2}$ for $\mathrm{BMl}$; $32.00 \pm 2.76 \mathrm{~cm}$ for $\mathrm{AC}$; and $33.93 \pm 4.47 \mathrm{~cm}$ for $\mathrm{CC}$. As for the non dysphagic group, it was of: $\mathrm{BMl}=26.43 \pm 4.42 \mathrm{~kg} / \mathrm{m}^{2} ; \mathrm{AC}=$ $30.72 \pm 3.66 \mathrm{~cm}$; and $\mathrm{CC}=35.25 \pm 5.59 \mathrm{~cm}$, without significant difference between the groups $(p>0.05)$. No dysphagic patient was classified by the MNA with normal nutritional status; an association between the presence of dysphagia and the risk of malnutrition was observed, according to this assessment ( $p=0.028$ ). 
The average scores obtained in the MNA were of $19.08 \pm 4.3$ in the group with dysphagia, and 24.33 \pm 5.10 in the group without dysphagia, without significant difference $(p>0.05)$.

The dysphagic group presented a lower consumption of calories and proteins. However, there were observed no differences between the groups regarding averages found of consumption or offer of calories and protein. This group had lower and significant hydric intake in relation to the group without dysphagia $(p=0.045)$.

Table 2. Comparison of the nutritional status between dysphagic and non dysphagic elderly hospitalized in a public hospital. Recife, Pernambuco, Brazil, 2015

\begin{tabular}{|c|c|c|c|c|}
\hline \multirow[b]{2}{*}{ Variables } & \multicolumn{3}{|c|}{ Dysphagia } & \multirow[b]{2}{*}{ P- valuex } \\
\hline & $\begin{array}{l}\text { Total } \\
\text { n (\%) }\end{array}$ & $\begin{array}{c}\text { Yes } \\
\text { n (\%) }\end{array}$ & $\begin{array}{c}\text { No } \\
\text { n (\%) }\end{array}$ & \\
\hline \multicolumn{5}{|l|}{$\mathrm{BMI}^{\dagger}$} \\
\hline Thinness & $2(16.7)$ & $1(16.7)$ & $1(16.7)$ & 1.000 \\
\hline Eutrophy & 4 (33.3) & $2(33.3)$ & $2(33.3)$ & \\
\hline Overweight/obesity & $6(50.0)$ & $3(50.0)$ & $3(50.0)$ & \\
\hline \multicolumn{5}{|l|}{$\mathrm{AC}^{+t}$} \\
\hline Thinness & $1(8.3)$ & $0(0.0)$ & $1(16.7)$ & 1.000 \\
\hline Eutrophy & $8(66.7)$ & $4(66.7)$ & $4(66.6)$ & \\
\hline Excessive weight & $3(25.0)$ & $2(33.3)$ & $1(16.7)$ & \\
\hline \multicolumn{5}{|l|}{$\mathrm{CC}^{\ddagger}$} \\
\hline Malnutrition & $2(16.7)$ & $1(16.7)$ & $1(16.7)$ & 1.000 \\
\hline Eutrophy & $10(83.3)$ & $5(83.3)$ & $5(83.3)$ & \\
\hline \multicolumn{5}{|l|}{ MNA" } \\
\hline Malnutrition & $2(16.7)$ & $1(16.7)$ & $1(16.7)$ & 0.028 \\
\hline Risk of malnutrition & $6(50.0)$ & $5(83.3)$ & $1(16.7)$ & \\
\hline Eutrophy & 4 (33.3) & $0(0.0)$ & $4(66.6)$ & \\
\hline
\end{tabular}

$\left({ }^{\star}\right)$ Fisher's exact test for the association of the variables; $(\dagger) \mathrm{BMI}=$ body mass index; ( $\left.\dagger+\right) \% \mathrm{AC}$ adequacy = percentage of adequacy of arm circumference; ( $\ddagger$ ) $\mathrm{CC}=$ calf circumference; (I) MNA = Mini-Nutritional Assessmentl

Table 3. Caloric, protein and hydric intake of dysphagic and non dysphagic elderly hospitalized in a public hospital. Recife, Pernambuco, Brazil, 2015

\begin{tabular}{lccc}
\hline \multirow{2}{*}{ Variables } & \multicolumn{2}{c}{ Dysphagia } & \\
\cline { 2 - 3 } & $\begin{array}{c}\text { Sim } \\
\text { Média } \pm \text { DP }\end{array}$ & $\begin{array}{c}\text { Não } \\
\text { Média } \pm \text { DP }\end{array}$ & P- value* \\
\hline Calories offered $(\mathrm{kcal})$ & $2018.78 \pm 361.89$ & $2181.54 \pm 123.67$ & 0.337 \\
Calorie intake $(\mathrm{kcal})$ & $1403.93 \pm 718.31$ & $1912.50 \pm 323.40$ & 0.144 \\
Protein offered $(\mathrm{g})$ & $108.18 \pm 31.88$ & $114.28 \pm 16.71$ & 0.749 \\
Protein intake $(\mathrm{g})$ & $70.01 \pm 36.75$ & $99.94 \pm 30.08$ & 0.201 \\
Hydric intake $(\mathrm{mL})$ & $1125.57 \pm 675.35$ & $1840.42 \pm 667.50$ & $\mathbf{0 . 0 4 5}$ \\
\hline
\end{tabular}

*Mann-Whitney test for the comparison between the groups; $\mathrm{SD}=$ standard deviation; kcal: kilocalorie; $\mathrm{g}=\mathrm{gram}$; $\mathrm{mL}=$ milliliter. 


\section{DISCUSSION}

Stroke was the main reason for hospital admission in the sample studied, and arterial hypertension and diabetes mellitus the main comorbidities. Most of the patients with dysphagia presented risk of malnutrition and malnutrition according to the MNA, even though the anthropometric parameters indicated absence of impaired nutritional status. This group also presented lower hydric intake.

The prevalence and report of previous stroke found in this study were superior to those identified by Panissa e Vassimon ${ }^{23}$, who reported a prevalence of stroke of $14 \%$, and report of previous stroke of $31 \%$ in the sample of 51 hospitalized elderly. Another paper ${ }^{24}$ found a report of previous stroke in $20 \%$ of the patients admitted post-stroke in a public hospital. Between 2009 and 2016, the elderly were responsible for the highest rates of hospitalization and mortality by stroke in Brazilian public hospitals ${ }^{25}$. In Brazil, the incidence of hemorrhagic stroke is of approximately $26 \%$, while $73 \%$ are of the ischemic type. Both types can cause dysphagia; nonetheless, the degree of swallowing difficulty may be related to the type of stroke ${ }^{26}$. When dysphagia is manifested in consequence of stroke, it may be considered morbidity, depending on the lesion and on the patient's age ${ }^{27}$. Arterial hypertension was associated to the presence of post-stroke dysphagia in a sample of 206 elderly ${ }^{28}$ and diabetes mellitus was also identified as predictive of development of poststroke swallowing disorders in elderly ${ }^{29}$. A study carried out with 100 post-stroke hospitalized patients showed a prevalence of dysphagia in $52 \%$, and arterial hypertension in $82.7 \%$ of the individuals ${ }^{24}$.

In the nutritional status assessment, it was observed a prevalence of individuals with eutrophy and excessive weight similar to another study, which also assessed patients admitted post-stroke, in which the average BMl was of $27.91 \pm 4.91 \mathrm{~kg} / \mathrm{m}^{2}$, andage average was of $75.81 \pm 6.73$ years $^{30}$. A research carried out with a population of 222 post-stroke hospitalized individuals also observed a prevalence of non-malnourished persons, according to BMl, at hospital admission, in which $55 \%$ of the patients were eutrophic, $14.7 \%$ with overweight, $5 \%$ obese, and $25.2 \%$ with malnutrition. However, after 14 days of hospitalization, an increase in the number of malnourished people was observed ${ }^{31}$. Another paper also showed a lower percentage of malnourishment, according to BMI, in a population of 200 elderly averaging $72.6 \pm 8.3$ years old, similar to this study, in which $39 \%$ were classified with eutrophy,
$36 \%$ with excessive weight, and $25 \%$ with malnutrition; the average BMl found was of $25.5 \pm 5.5 \mathrm{~kg} / \mathrm{m}^{2,32}$.

Although the percentage of malnourished people by BMI was lower in this study, the number of hospitalized patients with malnutrition is high, and it is already considered a public health problem in Brazilian hospitals, as well as in other underdeveloped and developed countries ${ }^{33}$. In a previous research, there was found a percentage of $41 \%$ of malnutrition, $33 \%$ of eutrophy, and $25 \%$ of excessive weight according to $\mathrm{BMI}^{23}$; the averages obtained for the values of $\mathrm{MBI}$, $A C$ and $C C$ were inferior to those in this study among elderly averaging $76 \pm 9$ years old. A prevalence of malnutrition in the elderly population is reported ${ }^{34}$; however, a smaller amount of malnourished elderly in this paper, according to BMI, may be justified by the participation of individuals with age between 60 and 80 years, differently from other researches, whose sample encompassed older people ${ }^{22,35}$; furthermore, one of them observed that the elderly in the age group of 80 and over have significantly lower values of BMI when compared to those aged from 60 to 69 years, and 70 to 79 years $^{35}$. It is known that, with age, involuntary weight loss, decreased appetite, and physiologic alterations may take place, contributing to malnutrition ${ }^{34}$. Moreover, overweight and obesity may also be present in the elderly population as a reflex of the nutritional transition process. This fact was observed in a research with 819 hospitalized patients, whose aim was to investigate the reflex of nutritional transition on the nutritional status and body composition of hospitalized patients, demonstrating that $47.8 \%$ had obesity, and $76.4 \%$ presented central adiposity, regardless of gender, age and reason for admission ${ }^{36}$.

The prevalence of patients with risk of malnutrition according to the MNA was higher in the dysphagic group. Dysphagia was identified as an independent risk factor of malnutrition in a sample of 1662 elderly hospitalized because of acute illnesses, in which the prevalence of malnutrition according to MNA was of $45.3 \%$ in dysphagic patients, and of only $18 \%$ in those without dysphagia ${ }^{37}$. As in this study, another paper also found a lower score in MNA questionnaire for dysphagic patients in relation to those without post-stroke dysphagia and, consequently, a higher risk of malnutrition ${ }^{30}$. The presence of dysphagia was also associated with the risk of malnutrition and the worsening of nutritional status in the first 14 days of hospital stay ${ }^{31}$. The MNA is considered a predictor of the elderly's health condition, and thus useful for the 
early identification of malnutrition ${ }^{38}$. Nevertheless, its use must not discard the application of other nutritional indicators.

The diet of individuals with dysphagia may need a modification in consistency and texture of foods, both solid and liquid ${ }^{4,7}$, besides restrictions on some foods considered as of risk of bronchoaspiration, such as cereals, foods with fibers, seeds or fish bones, among others ${ }^{7}$, so as to promote a safer and easier oral food ingestion. However, the low acceptability of the modified diet, and consequently the lower adherence to it, may increase the risk of nutritional deficiency in elderly with dysphagia ${ }^{39}$. Other factors that may contribute to a food intake incompatible with the nutritional needs in dysphagic elderly are: fear of feeding oneself, anorexia, and the difficulty itself in oral food intake ${ }^{8}$. A study that assessed 18 individuals with post-stroke dysphagia verified an average calorie intake significantly inferior to the average obtained for non dysphagic patients (637 $\pm 342 \mathrm{kcal} /$ day vs. $1214 \pm 247 \mathrm{kcal} /$ day $)^{40}$.

The dysphagic group presented a liquid intake decrease when compared to the non dysphagic group, which was also observed by Bannerman and McDermott ${ }^{41}$, who evaluated the food consumption of 30 hospitalized elderly, $50 \%$ of whom received diet modified for dysphagia, and verified in them a lower liquid intake, with an average of $1192 \pm 288 \mathrm{~mL} /$ day. A lower oral hydric intake among dysphagic patients was also verified by other researchers during hospital stay, when compared to the individuals without dysphagia $\left(511 \pm 560 \mathrm{~mL} /\right.$ day vs. $1730 \pm 472 \mathrm{~mL} /$ day $(\mathrm{p}<0.01)^{40}$. The decrease in liquid intake may be well explained by the need to use thickeners. A review demonstrated that the people who need thickened liquids present a lower consumption of them, which is even more decreased when there is an increase in the amount of thickener used, in order to get to the desired consistency. The use of a greater amount of thickener was also related to malnutrition, so that the minimum prescription to promote safe swallowing is recommended, as well as a more intense therapy with the purpose of returning to normality, aiming at taking not-thickened liquids ${ }^{42}$.

In this study, only $33.3 \%$ of the patients were precociously assessed by the speech-language-hearing therapist. It is important to highlight that the precocious assessment of these patients by a speech-languagehearing therapist may not happen in institutions whose evaluation request is done through medical demand, even for patients at risk of dysphagia, which is the case of the institution where this study was conducted. The precocious assessment and detection of dysphagia are important for the safe offer of foods, liquids and medications via oral route, in order to reduce complications and morbidity ${ }^{43}$. It is important that the different health professionals engaged in following up these patients be sensitive to the importance of speech-language-hearing assessment, having in view the primary disease, clinical background and comorbidities at hospital adimission ${ }^{18}$. It is further necessary that the institutions establish dysphagia risk screening protocols in elderly ${ }^{18,24}$.

Among the limitations of this paper, there should be highlighted the limited number of the sample, as well as the dependence for the collection of information from the medical records, as these are not computerized. Furthermore, the cross-sectional design did not allow associations to be made between the time of speechlanguage-hearing therapy, alterations in nutritional status, and the evolution of levels in the FOIS scale during hospital stay. Additional studies are suggested for the assessment of macro- and micronutrients consumption, and of the factors that may be associated with the degree of dysphagia and the nutritional evolution of the patients during hospital stay.

\section{CONCLUSION}

The dysphagic group presented risk of malnutrition according to the MNA, which is a useful tool for the early identification of nutritional risk in dysphagic elderly, even without signs of nutritional depletion in the anthropometric assessment. Moreover, there was a lower hydric intake in this group. The inadequate ingestion of liquids in these patients may result in dehydration, with risk of hydro-electrolytic disorders, urinary infections, and alterations in awareness level, further impairing food consumption. Although not statistically significant, the amount of calories and protein consumed was lower in the dysphagic group, which warns of the need of early intervention, in order to prevent complications. The integration between the nutritionist and the speechlanguage therapist is part of the set of basic care to be offered to these patients, as the progression in food intake and improvement in nutritional status depend on the swallowing process.

\section{REFERENCES}

1. Malagelada J, Bazzoli F, Boeckxstaens G, De Looze D, Fried M, Kahrilas $P$ et al. Dysphagia. World Gastroenterology Organisation Global Guidelines: 
Dysphagia. World Gastroenterology Organisation; 2014.

2. Boccardi V, Ruggiero C, Patriti A, Marano L. Diagnostic assessment and management of dysphagia in patients with Alzheimer's disease. $\mathrm{J}$ Alzheimers Dis. 2016;50(4):947-55.

3. Burgos R, Bretón I, Cereda E, Desport JC, Dziewas $\mathrm{R}$, Genton $\mathrm{L}$ et al. ESPEN guideline clinical nutrition in neurology. Clinical Nutrition. 2018;37(1):354-96.

4. Gallegos C, Brito-de la Fuente G, Clavé P, Costa A, Assegehegn $G$. Nutritional aspects of dysphagia management. Adv Food Nutr Res. 2017;81:271-318.

5. Sanchéz-Heredero MJG, Vaquero CS, Saéz MC, López FM, Garcia RS, Rincón M. Malnutrición asociada a disfagia orofaríngea en pacientes mayores de 65 años ingresados en una unidad médico-quirúrgica. Enferm Clin. 2014;24(3):183-90.

6. Silva LBC, Ikeda CM. Cuidado nutricional na disfagia: uma alternativa para maximização do estado nutricional. Rev. Bras. Nutr. Clin. 2009;24(3):203-10.

7. Gonzaléz LL, Enterría PG. Tratamiento nutricional de la disfagia orofaríngea. Endocrinol Nutri. 2006; 53(5):309-14.

8. Sonsin PB, Bonfim C, Silva ALND, Caruso L. Análise da assistência nutricional a pacientes disfágicos hospitalizados na perspectiva de qualidade. $O$ Mundo da Saúde. 2009;33(3):310-9.

9. Oliveira MMG, Teruel SL, Lima JL, Bergamasco $\mathrm{CM}$, Aquino RC. Terapia nutricional em disfagia: a importância do acompanhamento nutricional. Rev. Bras. Ciênc. Saúde. 2008;ano 6(16):71-6.

10. Guigoz Y. The mini-nutritional assessment (MNA $\AA)$ review of literature - what does it tell us? J. Nutr. Health Aging. 2006;10(6):466-85.

11. Lee RD, Nieman DC. Nutritional assessment. $2^{\underline{a}}$ ed. St Louis: Mosby; 1995.

12. Chumlea WC, Roche AF, Steinbaugh ML. Estimating stature from knee height for persons 60 to 90 years of age. J Am Geriatr Soc. 1985;33(2):116-20.

13. Lipschitz DA. Screening for nutritional status in the elderly. Primary Care. 1994;21(1):55-67.

14. Sampaio LR. Avaliação nutricional e envelhecimento. Rev. Nutr. 2004;17(4):507-14.

15. Blackburn GL, Thornton PA. Nutritional assessment of the hospitalized patients. Med. Clin. North. Am. 1979;63(5):11103-15.

16. World Health Organization. Physical Status: The use and interpretation of anthropometry. Geneva; 1995.
17. Harris JA, Benedict FG. A biometric study of basal metabolism in man. 1a edição. Boston: Carnegie Institute of Washington; 1919.

18. Sociedade Brasileira de Geriatria e Gerontologia. I Consenso Brasileiro de Nutrição e Disfagia em Idosos Hospitalizados. $1 \underline{\text { a }}$ edição. Barueri, SP: Minha Editora; 2011.

19. Tabela Brasileira de Composição de Alimentos-TACO / NEPA, UNICAMP. 4a edição. Campinas: NEPA UNICAMP; 2011.

20. Pesquisa de Orçamentos Familiares 2008-2009: tabelas de composição nutricional dos alimentos consumidos no Brasil/ Instituto Brasileiro de Geografia e Estatística- IBGE. Ministério do Planejamento, Orçamento e Gestão; 2011.

21. Abdulmassih EMS, Filho EDM, Santos RS, Jurkiewicz AL. Evolução de pacientes com disfagia orofaríngea em ambiente hospitalar. Arq. Int. Otorrinolaringol. 2009;13(1):55-62.

22. Silvério CC, Hernandez AM, Gonçalves MIR. Ingesta oral do paciente hospitalizado com disfagia orofaríngea neurogênica. Rev. CEFAC. 2010;12(6):964-70.

23. Panissa CO, Vassimon MS. Risco de desnutrição de idosos hospitalizados: avaliando ingestão alimentar e antropometria. Demetra. 2012;7(1):13-22.

24. Mourão AM, Almeida EO, Lemos EMA, Vicente LCC, Teixeira AL. Evolution of swallowing in post-acute stroke: a descriptive study. Rev. CEFAC. 2016;18(2):417-25.

25. Dantas LF, Marchesi JF, Peres IT, Hamacher S, Bozza FA, Quintano Neira RA. Public hospitalizations for stroke in Brazil from 2009 to 2016. PLOS ONE. 2019;14(3):1-10.

26. Paixao CT, Silva LD, Camerini FG. Perfil da disfagia após um acidente vascular cerebral: uma revisão integrativa. Rev. Rene. 2010;11(1):181-90.

27. Itaquy RB, Favero SR, Ribeiro MC, Barea LM, Almeida ST, Mancopes R. Disfagia e acidente vascular cerebral: relação entre 0 grau de severidade e o nível de comprometimento neurológico. J. Soc. Bras. Fonoaudiol. 2011;23(4):385-9.

28. Pena-Chavez R, López-Espinoza M, GusmánInostroza M, Jara-Parra M, Sepúlveda-Arriagada $\mathrm{C}$, Sepulveda-Arriagada $\mathrm{C}$ et al. Factors associated with post stroke oropharingeal dysphagia. Rev. Neurol. 2015;1(61):295-300.

29. Remesso GC, Fukujima MM, Chiappetta AL, Oda AL, Aguiar AS, Oliveira A de $S$ et al. Swallowing 
disorders after ischemic stroke. Arq. Neuropsiquiatr. 2011;69(5):785-9.

30. Espuela FL, Cuenca JCP, Mohedas MH, Sanchéz JMP, Cordovilla-Guardia S, Naranjo IC. Valoración nutricional y su relación con la situación funcional tras sufrir un ictus. Nutr Hosp. 2017;34(6):1353-60.

31. Diendéré J, Millogo A, Preux PM, Jesus $P$, Desport JC. Changes in nutritional state and dysphagia in stroke patients monitored during a 14-day period in a Burkina Faso hospital setting. Nutrition. 2018;48:55-60.

32. Brock F, Bettinelli LA, Dobner T, Stobbe JC, Pomatti $\mathrm{G}$, Telles CT. Prevalence of hypoalbuminemia and nutritional issues in hospitalized elders. Rev. Latino-Am. Enfermagem. 2016;24:e2736:e2736.

33. Toledo DO, Piovacari SMF, Horie LM, Matos LBN, Castro MG, Ceniccola GD et al. Campanha "Diga não à desnutrição": 11 passos importantes para combater a desnutrição hospitalar. BRASPEN J. 2018;33(1):86-100.

34. Fidelix MSP, Santana AFF, Gomes JR. Prevalência de desnutrição hospitalar em idosos. RASBRAN. 2013;5(1):60-8.

35. Pala D, Silva LF, Bastos AQA, Silva WM, Nemer ASA. Perfil nutricional de idosos hospitalizados. Rev Bras Nutr Clin. 2011;26(4):227-33.

36. Portero-Mclellan KC, Bernardi JLD, Jacob $P$, Soares CST, Frenhani PB, Mehri VAL. Estado nutricional e composição corporal de pacientes hospitalizados: reflexo da transição nutricional. RBPS. 2010;23(1):25-33.

37. Carrión S, Cabré M, Monteis Roca M, Palomera $E$, Serra-Prat $M$, Rofes $L$ et al. Oropharyngeal dysphagia is a prevalent risk factor for malnutrition in a cohort of older patients admitted with an acute disease to a general hospital. Clinical Nutrition. 2015;34(3):436-42.

38. Maciel JRV, Oliveira CJR, Tada CMP. Associação entre risco de disfagia e risco nutricional em idosos internados em hospital universitário de Brasília. Rev. Nutr. 2008;21(4):411-21.

39. Sura L, Madhavan A, Carnaby G, Crary MA. Dysphagia in the elderly: management and nutritional considerations. Clin Interv Aging. 2012;7:287-98.

40. Buoite SA, Gaio M, Furlanis G, Douglas P, Naccarato $M$, Manganotti P. Fluid and energy intake in stroke patients during acute hospitalization in a stroke unit. J Clin Neurosci. 2019;62:27-32.
41. Bannerman E, McDermott K. Dietary and fluid intakes of older adults in care homes requiring a texture modified diet: the role of snacks. J Am Med Dir Assoc. 2011;12(3):234-9.

42. Chicero JAY. Thickening agents used for dysphagia management: effect on bioavailability of water, medication and feelings of satiety. Nutr $\mathrm{J}$. 2013;12(54):1-8.

43. Padovani AR, Moraes DP, Sassi FC, Andrade CRF. Clinical swallowing assessment in intensive care unit. CODAS. 2013;25(1):1-7. 